\title{
Cyclotella paleo-ocellata, a new centric diatom (Bacillariophyta) from Lake Kinneret (Israel)
}

\author{
Hannah Vossel ${ }^{1}$, Jane M. Reed ${ }^{2}$, Václav Houk ${ }^{3}$, Aleksandra CvetKoska ${ }^{4} \&$ Bart \\ VAN DE VIJVER ${ }^{5,6}$
}

\author{
${ }^{1}$ Rheinische Friedrich-Wilhelms-University of Bonn, Steinmann Institute of Geology, Mineralogy \& \\ Paleontology, Nussallee 8, 53115 Bonn, Germany; Corresponding author e-mail: hvossel@uni-bonn.de \\ ${ }^{2}$ University of Hull, Department of Geography, Environment and Earth Sciences, Cottingham Road, Hull, HU6 \\ $7 R X$, United Kingdom \\ ${ }^{3}$ Institute of Botany, C.A.S. Dukelská 135, 37982 Třebon̆, Czech Republic \\ ${ }^{4}$ University of Ss Cyril and Methodius, Faculty of Natural Sciences, Institute of Biology, Arhimedova 3, 1000 \\ Skopje, R. Macedonia \\ ${ }_{5}^{5}$ Botanic Garden Meise, Department of Bryophyta \& Thallophyta, Nieuwelaan 38, B-1860 Meise, Belgium \\ ${ }^{6}$ University of Antwerp, Department of Biology, ECOBE, Universiteitsplein 1, B-2610 Wilrijk, Antwerpen, \\ Belgium
}

\begin{abstract}
Large, subfossil populations of an unknown centric, planktonic diatom were observed in a lake sediment core from Lake Kinneret (Israel), which is here described as Cyclotella paleo-ocellata sp. nov. The new taxon, which belongs to the Cyclotella ocellata species complex, is described and separated from other similar taxa (e.g., Cyclotella ocellata, Cyclotella kuetzingiana, Cyclotella polymorpha, Cyclotella paraocellata) based on a combination of the following morphological characters: valve diameter, number of orbiculi depressi (circular depressions), number of striae/10 $\mu \mathrm{m}$, stria length, number and position of rimoportulae and the number of central and marginal fultoportulae. Cyclotella paleo-ocellata can be distinguished mainly by two prominent characteristics: (1) the number and the arrangement of the orbiculi depressi (4-8) which increase with the valve diameter and (2) the marginal fultoportulae, situated on each, every second or third costa. Since Cyclotella paleo-ocellata is at present only known from the subfossil bottom sediments of Lake Kinneret, its ecological preferences are inferred simply from the associated diatom flora.
\end{abstract}

Key words: Bacillariophyta, Cyclotella paleo-ocellata, Lake Kinneret, morphology, taxonomy

\section{INTRODUCTION}

The genus Cyclotella (KüTZING) BRÉBISSON is one of the most commonly occurring genera of the Stephanodiscaceae (Houk et al. 2010). Its species are centric and characterized by a distinct central area and a radially-striated marginal area (HÅKANSSON 2002). Genera in the family of Stephanodiscaceae are a dominant component of the plankton in freshwaters worldwide. The genus Cyclotella often dominates species assemblages in paleolimnology, particularly in the circum-Mediterranean region, and can cause difficulties or loss of information in paleoenvironmental reconstructions due to the ongoing taxonomic uncertainty in this group (HÁKANSSON 2002). The genus exhibits a high morphological variability that is still not completely understood, requiring more detailed analysis of recent and fossil diatom material.

Within the genus Cyclotella, it is possible to distinguish several groups of taxa that show a more or less similar morphology. One of these groups is the 'species complex' of Cyclotella ocellata PANtOcseK, a term introduced by Hegewald \& HindÁKová (1997). CVetKoska et al. (2012) recently reviewed the complex in detail. Cyclotella ocellata was first described by Pantocser (1901, p. 104, fig.15: 318) as a flat valve with 3 "margaritis majoribus" (later named "orbiculi depressi" by Kiss et al. 1996) arranged in a triangular position in the central area with a ring of marginal striae.

As well as the high taxonomic variability within the taxon C. ocellata the ecological preferences are also still uncertain. According to several authors (e.g., Fritz et al. 1993; VAN DAM et al. 1994; KisS et al. 1996; Schlegel \& Scheffler 1999; Cremer \& Wagner 2003; Houk et al. 2010) C. ocellata seems to have an extremely broad tolerance of nutrient status, extending (in rare cases) from ultra-oligotrophic [e.g., Lake Ohrid (Cvetкoska et al. 2012)] to eutrophic [e.g., Lake Dagow (SChlegel \& SCheffler 1999)]. CREMER \& WAGNER (2003) suggested that the Cyclotella ocellata complex must comprise several different species or ecological groups, exhibiting contrasting ecological preferences for nutrient status 
which may in part relate to the biogeographic region in which they grow. Cyclotella ocellata is known as a cosmopolitan taxon, often found in shallow lake e.g., Lake Las Madres (Kiss et al. 1996) and Laguna de Medina (ReED et al. 2001) in Spain], but can also dominate in very deep lakes such as Ohrid (CVETKOSKA et al. 2012) or El'gygytgyn (CREMER \& WAGNER 2003), perhaps particularly those with a sandy or gravel lake bed (Houk et al. 2010). It also occurs in slow flowing rivers as plankton or periphyton (KRAMMER \& LANGEBertalot 1991; Енrlich 1995; Houk et al. 2010).

Few diatom-based paleolimnological studies have been carried out previously in lake sediments of ancient Lake Kinneret. Pollingher et al. (1984) analysed the changing character of planktonic diatoms in Lake Kinneret over the last 5000 yrs and EнRLICH (1985) carried out a paleoecological assessment of recent environmental change in the diatom flora of five short cores. This included the description of two new planktonic species: Cyclotella polymorpha MEYER et HȦKANSSON and Stephanodiscus galileensis HAKKANSSON et EHRLICH (HÁKANSSON \& EhrLICH 1987; MEYER \& et EHRLICH (HÁKANSSON \& EHRLICH 1987; MeYER \&
HÁkANSSON 1996). EHrLICH (1985) also observed a HAKANSSON 1996). EHRLICH (1985) also observed a Cyclotella sp. (Eupuch 1985: plate 1, figs 13-14) without formal description.

Diatom-based paleolimnological studies on

in Lake Kinneret. During a drilling campaign which took place as part of the Collaborate Research Center (CRC) 806 "Our Way to Europe" (http://www. sfb806.uni-koeln.de), a $17.8 \mathrm{~m}$ long sediment core wa recovered which spans the last c. $8200 \mathrm{yrs}$ cal BP. The detailed diatom-based paleolimnological analysis of this sediment sequence forms part of a multi-proxy study of Holocene climate change and human impact in the Levant region. During a preliminary analysis of the diatom succession in the sediment sequence of Lake Kinneret, large populations of an unknown Cyclotella species are often recorded as abundant in assemblages dominated by the classic Cyclotella ocellata type.

Following detailed light and scanning electro microscopy observation, the unknown taxon could no be identified based on the currently available literature. Here, we describe this new taxon as Cyclotella paleo-ocellata sp. nov. and discuss its morphology and separation from other taxa within the Cyclotella ocellata complex, also attempting the first delimitation of its ecological preferences.

\section{Materials AND METHODS}

Study site. Lake Kinneret(from Hebrew word kinnó $r=$ "harp' a longer timescale have not yet been accomplished Galilee or Lake Tiberias and is located in the northern part of

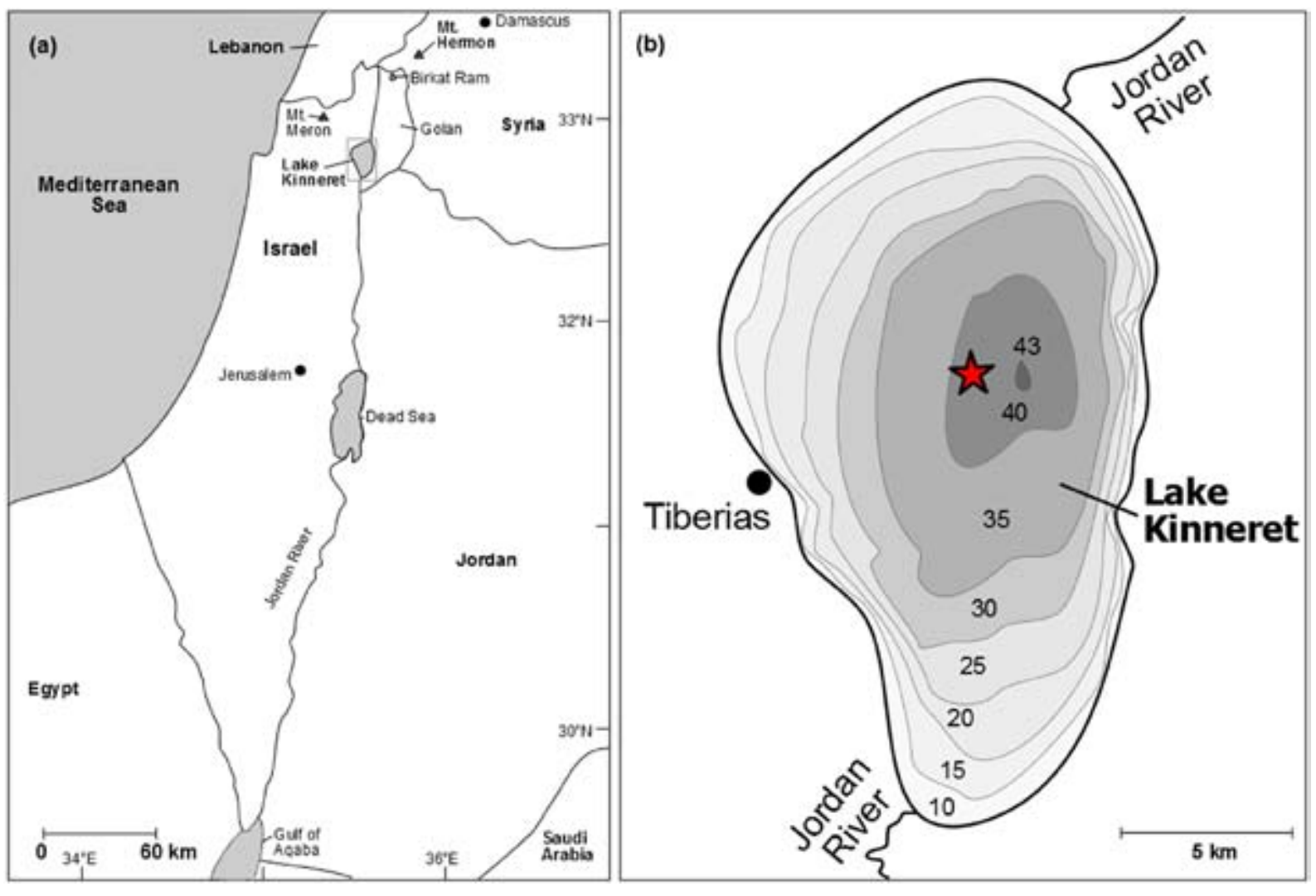

Fig. 1. (a) Location of Lake Kinneret in the North of Israel; (b) Bath
location is marked by a 'red star' (modified after SCHIEBEL, 2013). the Jordan Rift Valley in the North of Israel $\left(32^{\circ} 48^{\prime} 08.12^{\prime \prime} \mathrm{N}\right.$, $35^{\circ} 35^{\prime} 20.62$ "E; Fig. 1). It is situated, together with the Dead Sea basin, on the "Dead Sea Transform Fault (DSTF)". The DSTF currently forms a more than $1000 \mathrm{~km}$ long transform Sea with the Alpine conergent bon in Turkey (Hened et al. 2002). The modern and Holocene Sea of Galilee has evolved from ancient water bodies that filled the Kinneret ectonic depression in the northern Jordan basin during the Late Pleistocene (HAZAN et al. 2004). The lake basin is mainly surrounded by volcanic igneous rocks (basalts in the Golan Heights), which were formed during the Oligocene, Miocene and Pleistocene and now form escarpments of up to $00 \mathrm{~m}$ in height around the lake.

The lake is $22(\mathrm{~N}-\mathrm{S}) \mathrm{km}$ long, $12 \mathrm{~km}$ (W-E) wide and up to $43 \mathrm{~m}$ deep, and is situated $210 \mathrm{~m}$ below sea level. (total surface $=2730 \mathrm{~km}^{2}$ ) extends to parts of the Upper Galilee in NE Israel, the Golan Heights, the Hermon range (with the peak of Mt. Hermon at $2814 \mathrm{~m}$ a.s.l.) and the southern Anti-Lebanon mountains (BARUCH 1986). The lake is mainly fed from the north by the River Jordan, which also drains the lake southwards to the Dead Sea. The lake is warn and monomictic, being stratified with an anoxic hypolimnion from May to December and fully mixed from December to April (Gers $N$ 2002). An overiow of the main limnological composition of bottom sediments and secchi depth) are given in Table 1. Lake level fluctuates by up to $4 \mathrm{~m}$ dependins on precipitation, evaporation and water abstraction by the National Water Carrier operation. The Kinneret area has a Mediterranean climate, characterized by mild, rainy winters and hot, dry summers (BARUCH 1986).

Table 1. Table of typical annual limnological parameters for the epilimnion of Lake Kinneret based on the Lake Kinneret data base

\begin{tabular}{|c|c|c|}
\hline \multicolumn{3}{|c|}{ Chemical parameters } \\
\hline $\mathrm{pH}$ & 8.6 & \\
\hline Salinity (as $\mathrm{Cl}$ ) & 250 & mg. $1^{-1}$ \\
\hline Silica (as $\mathrm{SiO}_{2}$ ) & 9 & mg..$^{-1}$ \\
\hline Soluble $\mathrm{P}\left(\right.$ as $\mathrm{PO}_{4}$ ) & 2 & $\mu \mathrm{g} . \mathrm{r}^{-1}$ \\
\hline Total Phosphorus & 20 & $\mu$ g. $1^{-1}$ \\
\hline Nitrogen (as $\mathrm{NO}_{3}$ ) & 80 & $\mu \mathrm{g} . \mathrm{r}^{-1}$ \\
\hline \multicolumn{3}{|c|}{ Pelagic bottom sediments } \\
\hline Clay minerals & 35 & $\%$ \\
\hline Calcium carbonate & 55 & $\%$ \\
\hline Organic matter & 5 & $\%$ \\
\hline Residual & 3 & $\%$ \\
\hline Secchi depth & 2.6 & $\mathrm{~m}$ \\
\hline
\end{tabular}

Field and laboratory methods. Two parallel sediment cores (core KI_10_I and KI_10_II) were recovered from a water depth of $38.8 \mathrm{~m}$ at the central, deepest part of the in March 2010, ung 3 UWITEC Univ. 1 "' sed star') Platform (http://www uwitec at) with a piston corer system. Sediment cores were transported for storage to the University of Bonn. The $17.8 \mathrm{~m}$ continuous master sequence covers approximately the last $8200 \mathrm{cal}$ yrs BP (SCHIEBEL 2013). This diatom study is based on analysis of taxa observed at various core depths between $4.5 \mathrm{~m}$ and $10.0 \mathrm{~m}$, where the unknow species is abundant in the diatom flora.

All samples were prepared using standard techniques (BATAARBEE 1986). $0.2 \mathrm{~g}$ of wet sediment was treated with $\mathrm{H}_{2} \mathrm{O}$ organic matter. Afterwards a few drops of concentrated HCI $(35 \%)$ were added to the hot sample residual to remove carbonates. Samples were washed with distilled water an centrifuged several times $(1200 \mathrm{rpm}$ for $7 \mathrm{~min}$ ) to eliminate the acid residual and avoid dissolution during storage. The cleaned sample material is stored at $4{ }^{\circ} \mathrm{C}$ in a cooling chamber at the University of Bonn (Germany). A subsample from the cleaned, organic-free material was mounted in Naphrax ${ }^{\prime 4}$ for diatom community analysis using an Olympus BX53 ligh Differential Interference Contrast and an Olympus UC30 digital camera. For scanning electron microscopy (SEM) parts of the oxidized suspensions were filtered throug a $1-\mu \mathrm{m}$ Isopore ${ }^{\mathrm{TM}}$ polycarbonate membrane filter (Merck Millipore). The stubs were sputter-coated with a GoldPalladium layer of $20 \mathrm{~nm}$ and studied using a ZEISS Ultra SEM microscope at $3 \mathrm{kV}$ (Natural History Museum London, UK). Diatom terminology follows Ross et al. (1979), Kiss e The term 'orbiculi depressi' introduced by Kiss et al (1996) is used to indicate the shallow central depressions.

Fifty non-dissolved valves were photographed and used for morphometric analysis of the following valve features: diameter $(\mu \mathrm{m})$, length of the marginal striae $(\mu \mathrm{m})$, number of striae in $10 \mu \mathrm{m}$, number of central fultoportulac, number of orbiculi depressi, number of rimoportulae an number of costae between the marginal fultoportulae. Comparisons with other, similar Cyclotella tax are based on HAKANSSON (1990a, 1990b, 2002), KIss et al.

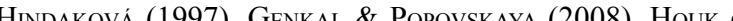
al. (2010) and CVETKosKA et al. (2014)

\section{RESULTS}

Cyclotella paleo-ocellata VOSsEL et $\mathrm{V}$ AN DE VIJVER sp. nov. (Figs 2-18, 20-34)

Description

Light microscopy (Figs 2-18): Valves circular, nearly lat. Valve diameter $(\mathrm{n}=50)$ : $14.1-28.7 \mu \mathrm{m}$. Three dome-shaped initial valves found (diameter 22.6-27.4 um) (Figs 17, 18). Central area colliculate (Figs 2 , $6,13,15$ ), between $1 / 2$ and $3 / 4$ of the valve diameter, clearly delimitable from marginal area. Orbicula depressions arranged concentrically in the centra area (Figs 4, 14), presenting occasionally a star- 


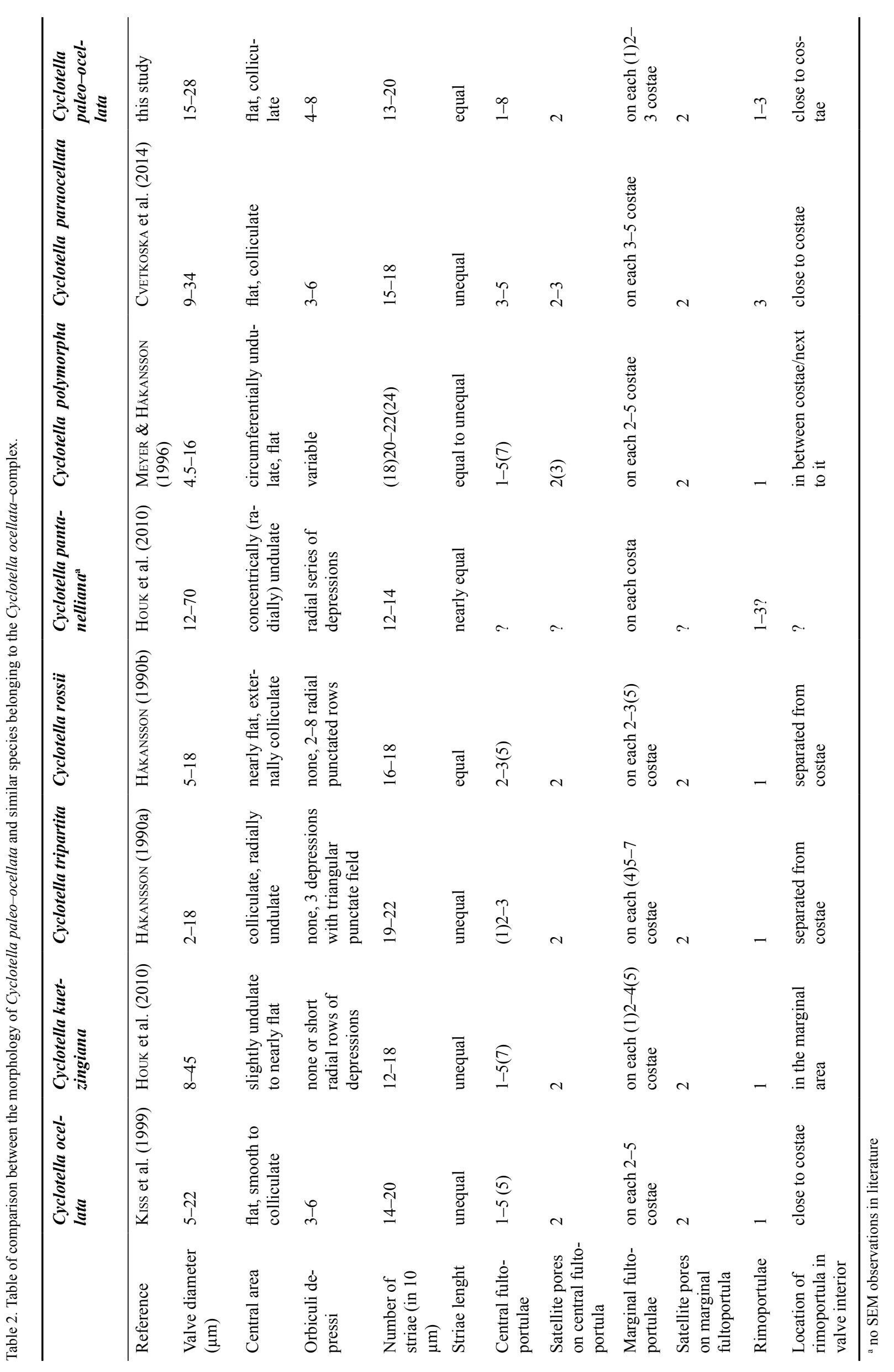

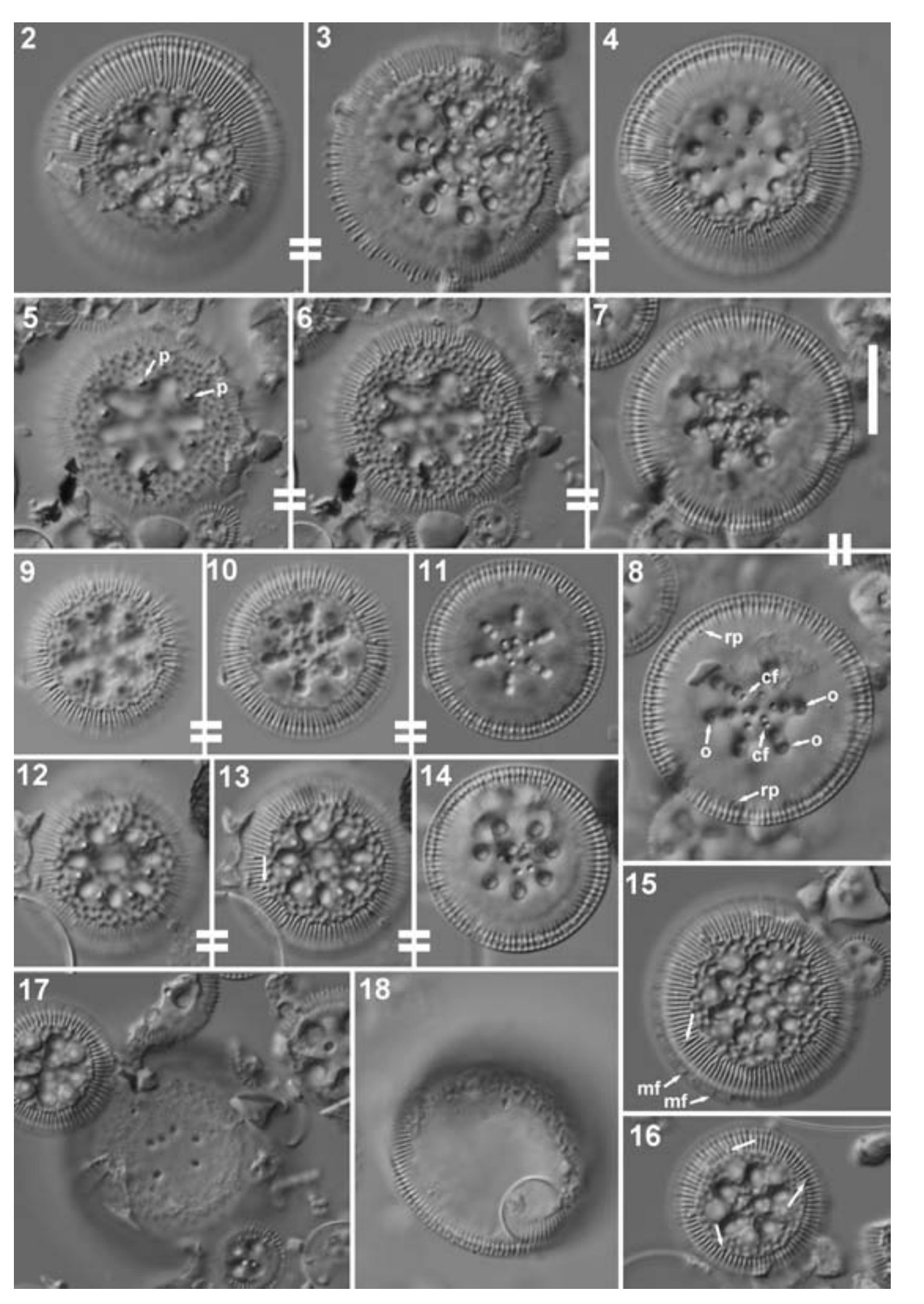

Figs 2-18. Photographs of the type population of Cyclotella paleo-ocellata sp. nov. from the subfossil bottom sediments of Lake Kinneret focus levels (indicated by ' $=$ ') to show all morphological details; (17-18) Initial cells. Scale bar $10 \mu \mathrm{m}$. Used abbreviations: (cf) central fultoportula, (mf) marginal fultoportulae, (o) orbiculi depressi, (p) papilla, (rp) rimoportula, arrows on Figs 13, 15-16= forked interstriae. 
shaped pattern (Figs 3, 7, 11). Number of orbicular depressions variable, 4-8 (Fig. 19B). Papillae present in between the depressions, in number always equal to the number of orbicular depressions ('p'; Fig. 5). Initial cells lacking any depressions or papillae (Figs 17, 18). Central fultoportulae easily visible by changing focu level, 2-8 (Fig. 19A) near the orbicular depression (cf'; Fig. 8). Rimoportulae, 1-2(3) present near the marginal striae ('rp'; Fig. 8). Marginal fultoportulae usually visible, separated by (0)1-2 costae ('mf'; Fig. 15). Near the rimoportulae, three costae separating djacent marginal fultoportulae. Marginal striae, 12 20 in $10 \mu \mathrm{m}$ (Fig. 19C), almost equal in length, 2.4-5.6 $\mu \mathrm{m}$, throughout the entire valve, never penetrating into the central area (Figs 2, 6, 10, 15). Some interstriae forked ('arrows'; Figs 13, 15, 16).

Scanning electron microscopy (Figs 20-34): Valve exterior: Valve face central area colliculate, covered by irregularly shaped, sized and scattered, usually rounded, hillock-likeprotuberances(Figs 20,21, 24). Orbiculi depressi (circular depressions) occurring as large, shallow depressions never penetrating the valve wall ('o'; Figs $20,21,23$ ), gradually decreasing in size towards the center. Ball-like silica granules, looking like large papillae, positioned outward between the orbicular depressions, decreasing in size towards the valve center when positioned in series on a ridge ('p'; Figs 20, 21, 23). When absent, the papilla where the silica granule (papilla) was originally located (Figs 20,21). Silica granules show an irregular colliculate surface sculptured by a series of ridges and small hillocks (Figs 23, 24)

Externally striae multiseriate, usually composed of two (outer) rows of larger areolae and 1-2 (inner) rows of small areolae (Figs 20, 24, 26), the latter situated between the rows of larger areolae. Near the valve margin, striae merging due to shortening of the interstriae bearing a marginal fultoportula ( $\mathrm{mr}$, Fig 24,26 ). Interstriae of irregular width, slightly raised above the level of the striae (Fig. 24). Conical spinulae present on each interstria, near the central area (' $\mathrm{s}$ ', Figs 24, 25). When absent, position of spinulae still visible as a shallow round depression (Figs 20, 24) Small granules $\left({ }^{\prime} \mathrm{g}\right)$ scattered on the interstriae. A series of cylindrical, blunt spines present near the valve margin ('ms'; Figs 20, 26 ('arrows'), 27).

Figs 20-27. External scanning electron microscopy view of Cyclotella paleo-ocellata sp. nov. (type population, Lake Kinneret, sample 4 444): granula (papilla) and its surface ornamentation; (23) Detailed external view of the central area showing radial rows of papillae and central fultoportulae; (24) Detailed external view of the central area and the marginal striae. Note the presence of spinulae, granulae, rimoportula an

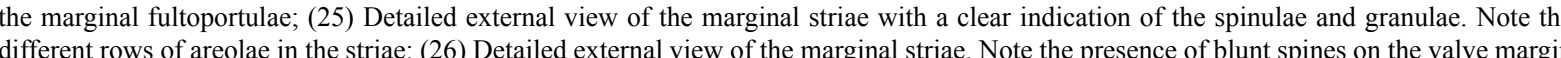
('arrows'); (27) Detailed picture of blunt spines. Scale bars $10 \mu \mathrm{m}(20,21,23), 1 \mu \mathrm{m}(22,24-27)$. Used abbreviations: (cf) central fultoportuh g) granula (mf) marginal fultoportula, (ms) marginal spins, (o) orbiculi depressi, (p) papilla, (pp) papilla-postament, (rp) rimoportula,
spinula.
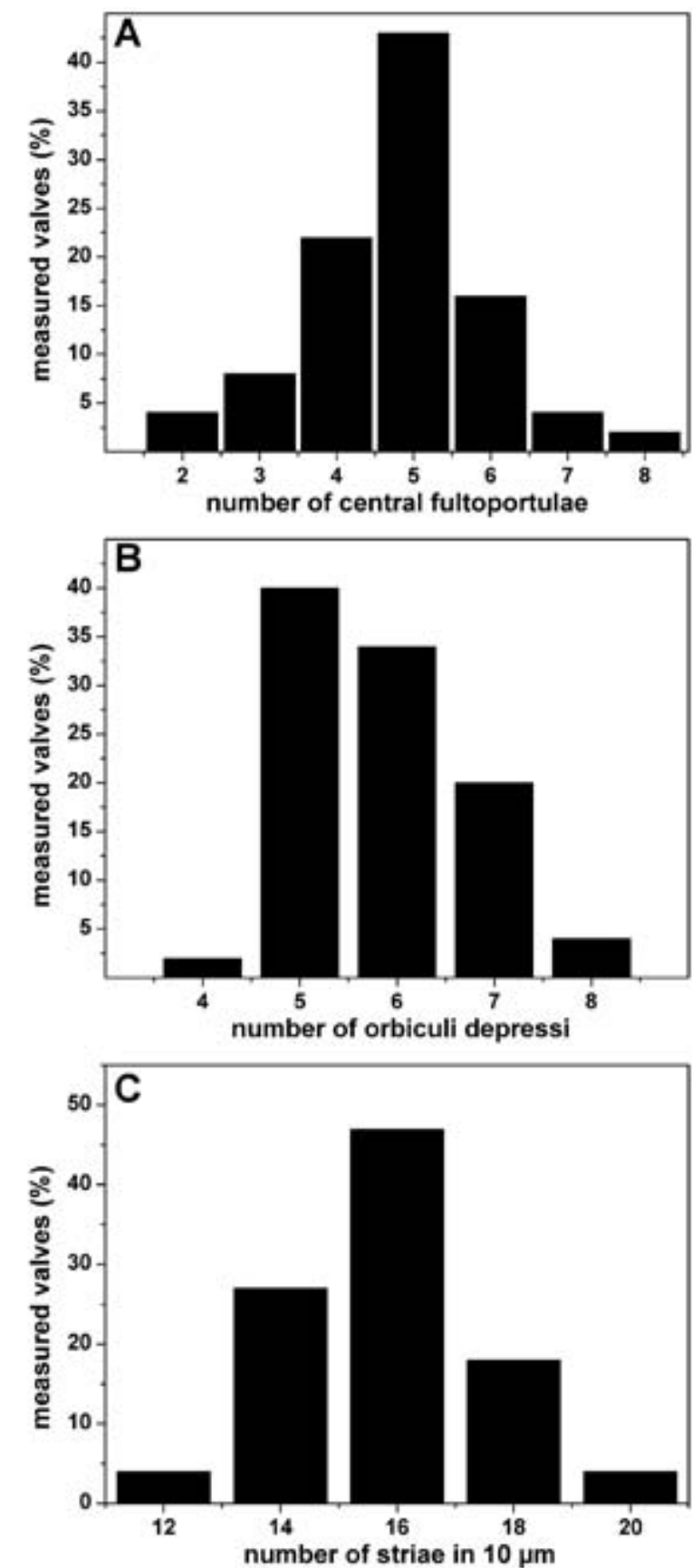

Fig. 19. Relation between measured valves of Cyclotella paleofultata $[$ in percentage; $\mathrm{n}=50]$ and $(\mathrm{A})$ the number of central
fultap; (B) the number of orbiculi depressi; and (C) the umber of striae in $10 \mu \mathrm{m}$

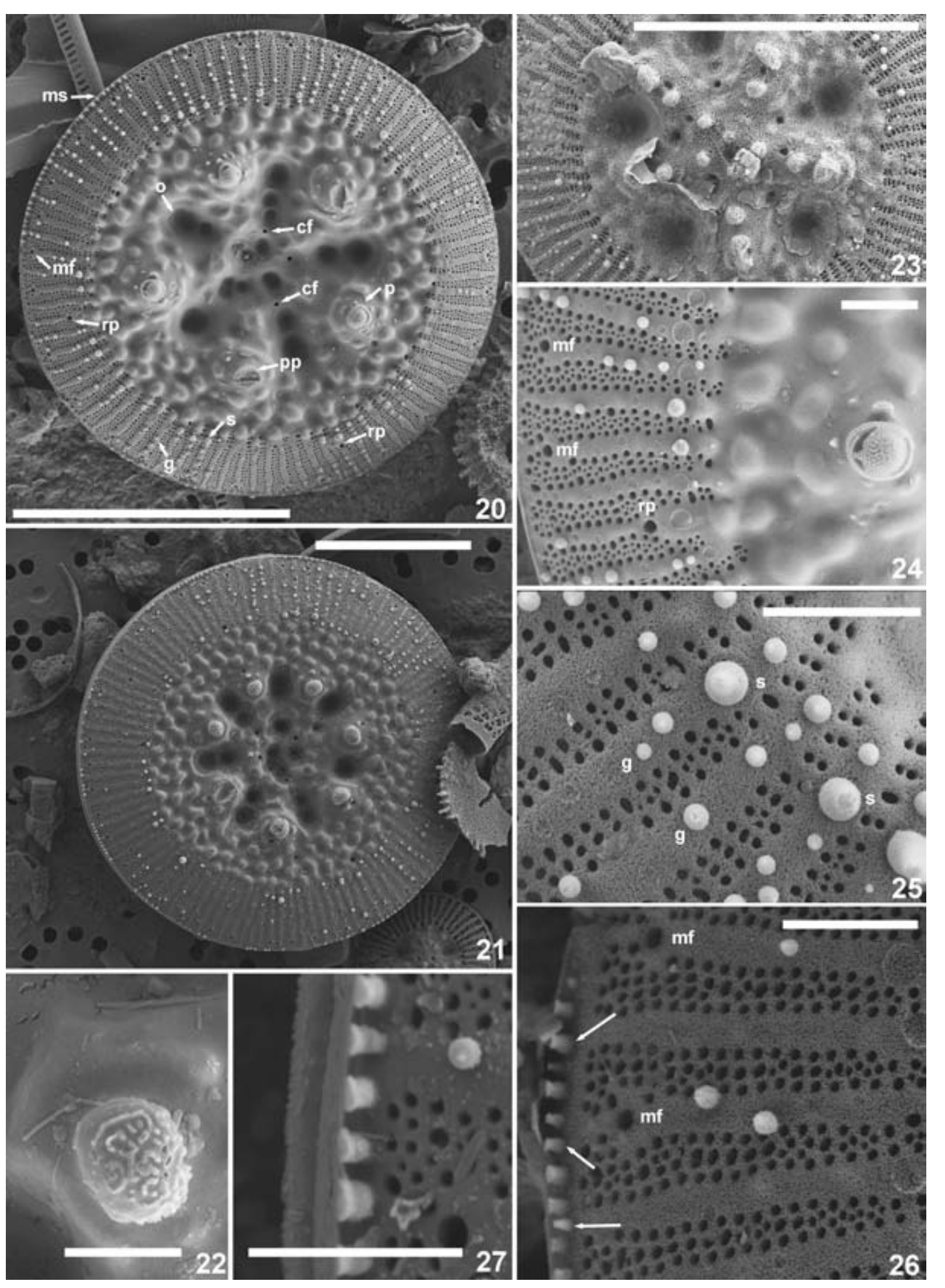




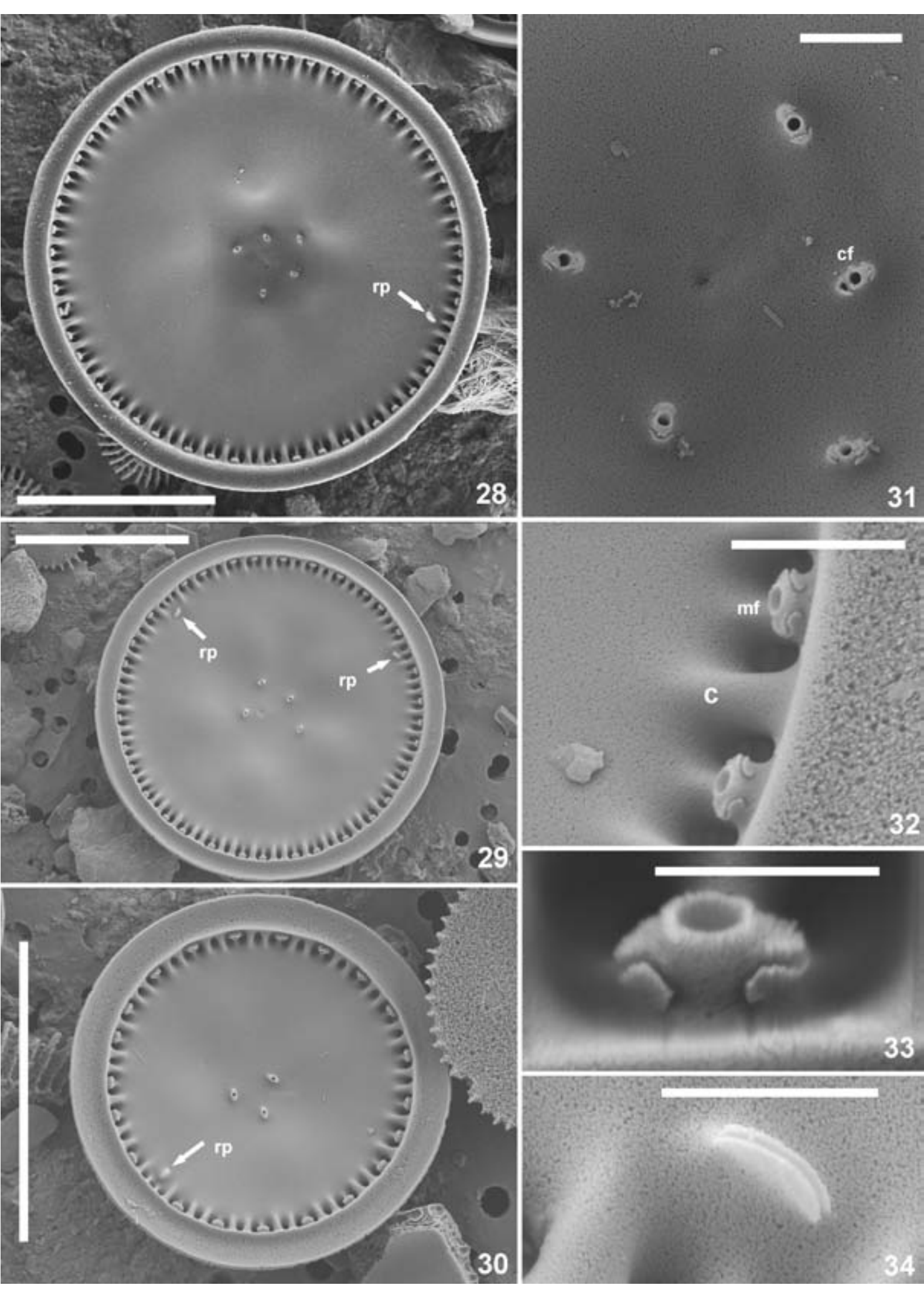

Figs 28-34. Internal scanning electron microscopy view of Cyclotella paleo-ocellata sp. nov. (type population, Lake Kinneret, sample H44):
(28-30) Internal view of complete valves with different organization of the central area; (31) Detailed view of the central fultoportulae howing two satellite pores per fultoportula; (32) Detailed picture of the marginal area showing two marginal fultoportulae (with two satellite arimoportula as a sessile labium with a wide slit. Scale bars $10 \mu \mathrm{m}(28-30), 1 \mu \mathrm{m}(31,32,34), 1 \mu \mathrm{m}$ (33). Used abbreviations: (c) costa, (cf) central fultoportula, (mf) marginal fultoportula, (rp) rimoportula
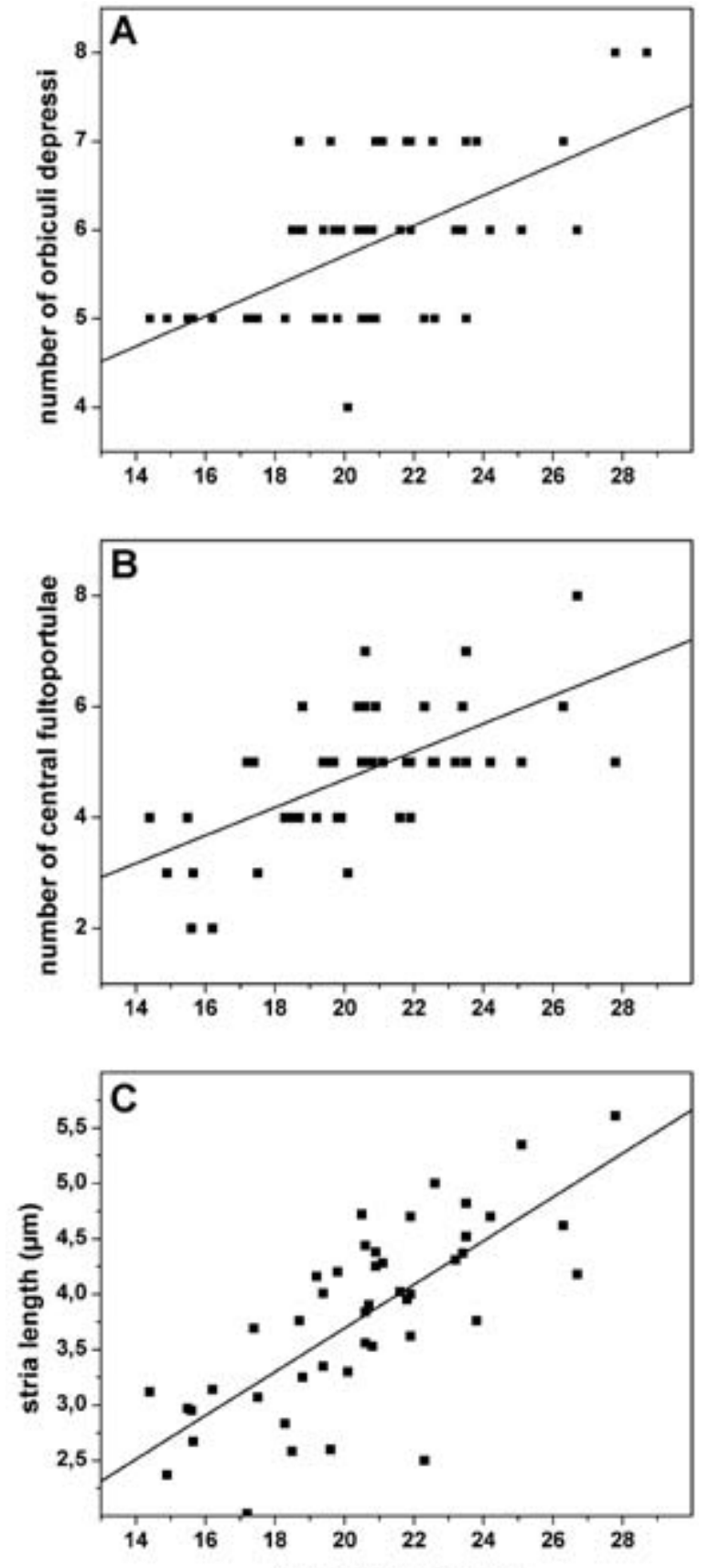

Valve diameter $(\mu \mathrm{m})$

Fig. 35. Relation between the valve diameter $(\mu \mathrm{m})$ of Cyclotell paleo-ocellata and (A) the number of orbiculi depressi $(\mathrm{r}=0.5955$ $\mathrm{p}<0.0001)$; (B) the number of central fultoportulae $(\mathrm{r}=0.63352$;
$<0.0001)$;nd (C) the stria len regression line is added to all graphs.

External openings of the central fultoportulae visible as mall, rounded pores ('cf'; Figs 20, 21, 23). Marginal fultoportulae visible externally as small, rounded pores on each or every second or third interstria, usually shortening the interstriae near the valve margin (Figs $20,24,26)$. Rimoportula(e) positioned on the interstriae close to the central area, present as small, rounded pores ('rp'; Figs 20, 24). When rimoportula present, marginal fultoportula absent, separating two adjacen marginal fultoportulae by 3 interstriae (instead of 1-2).

Valve interior: Valve face more or less flat with slightly undulating central area. Internal openings of the central fultoportulae present as short tubuli with two satellite pores ("cf"; Figs 28, 31). Near the valve margin interstriae (costae) composed of short stronger costae (ribs) without processes alternating thinne depressed costae bearing marginal fultoportulae, wit small alveolar openings between them ('mf'; Figs 28 , 30,32 ). Internal openings of the marginal fultoportulae surrounded by two satellite pores (Figs 32, 33). Rimoportula(e) present externally as a small circular opening, internally as a sessile labium with a wide slit with a variable orientation, usually radial ('rp'; 28,29 , $30,34)$.

Etymology: The specific epithet (paleo-ocellata) refers to the similarity with Cyclotella ocellata and the fact that, to date, the species has only been found in subfossil material from a sediment core.

Type locality: Lake Kinneret, Israel, sediment core KI10_II_4.8-5.8, sample H44 (Leg. LiTT et al.; coll. date $03 / 2010$ ).

Holotype (designated here): BR-4383 (Botanic Garden Meise, Belgium).

Isotypes (designated here): PLP-268 (University of Antwerp, Belgium); STIPB-Vossel-1 (SteinmannInstitute, Rheinische Friedrich-Wilhelms University of Bonn, Germany).

Associated diatom flora: Cyclotella paleo-ocellata is abundant over large parts of the sediment core (relative abundance often $>30 \%$ ), where Cyclotella ocellata is dominating the diatom flora. Other common taxa comprise various Stephanodiscus taxa including S. galileensis, Amphora taxa (e.g., A. indistinct LevKov and $A$. ovalis (KützING) KützzING), unidentified Staurosira and Staurosirella taxa and Aneumastus tax such as A. stroesei (ØstruP) D.G.MAnN et StickLe and A. tusculus (Ehrenberg) D.G.Mann et Stickie.

\section{Discussion}

Comparison with other taxa

Cyclotella paleo-ocellata belongs morphologically to the Cyclotella ocellata species complex, based on the presence of orbiculi depressi and papillae in the colliculate central area, and on the arrangement and position of marginal striae, rimoportulae an fultoportulae. Table 2 describes other taxa with which C. paleo-ocellata may be confused, demonstrating tha the new taxon is quite distinct based on the measure set of morphological characteristics. It differs from similar Cyclotella ocellata PANTOCSEK and Cyclotella kuetzingiana THWAlTES first of all in having margina 
fultoportulae situated on each, every second or third costa.

Cyclotella ocellata has a similar stria density but a contrasting stria organization, exhibiting marginal striae of unequal length whereas in C. paleoocellata all marginal striae have a more or less equal length. Moreover, $C$. ocellata is usually smaller (valve diameter 5-22 $\mu \mathrm{m}$ vs. $15-28 \mu \mathrm{m}$ in C. paleo-ocellata) with a lower number of orbiculi depressi (3-6 in $C$. ocellata vs. 5-8 in C. paleo-ocellata), a lower number of central fultoportulae (up to 5 vs. up to 8 in C. paleoocellata) and the marginal fultoportulae are positioned on each 2-5 costae whereas in C. paleo-ocellata this is limited to 1-3 costae. Kiss et al. $(1996,1999)$ discussed various biometrical ratios for $C$. ocellata. Figures 35 A-C show the same ratios for C. paleo-ocellata. All measured parameters are highly significant. Figure $35 \mathrm{~A}$ shows clearly that larger valves have a higher number of orbiculi depressi $(\mathrm{r}=0.5955, \mathrm{p}<0.0001)$ in contrast to $C$. ocellata where the number of orbiculi decreases with increasing valve diameter (Kiss et al. 1996). HEGEWALD \& HINDAKOVÁ (1997) made a similar observation in a study of a C. ocellata population from the Gallberg pond in NW-Germany (although the pictures shown in their publication clearly differ from the $C$. ocellata type species and appear to resemble more closely C. polymorpha), clearly indicating this important morphological difference between $C$. ocellata and C. paleo-ocellata. The number of central fultoportulae in relation to the valve diameter (Fig. $35 \mathrm{~B})$ shows a trend that is comparable to $C$. ocellata: larger valves tend to have a higher number of central fultoportulae $(r=0.6335, p<0.0001)$ (Kiss et al. 1996) Finally, stria length significantly increases with valve diameter (Fig. 35C) in C. paleo-ocellata $(\mathrm{r}=0.7475$, $\mathrm{p}<0.0001$ ), a feature not analysed in $C$. ocellata. Genkal \& Popovskaya (2008) analysed a C. ocellata population from Lake Khubsgul (southern Baikal basin, Mongolia). They observed larger valves (up to $40 \mu \mathrm{m}$ ) with a highly variable number of costae (2-8) between the marginal fultoportulae, a high number of central fultoportulae (1-13), which are often positioned very close to each other, and always 3-4 orbiculi depressi in the central area, regardless of the valve diameter. This combination of features has never been observed in C. paleo-ocellata and it is even highly likely that based on the differences between this taxon and the type species of $C$. ocellata, the Mongolian population may represents more than one taxon. C. ocellata and $C$. paleo-ocellata co-occur in our sediment samples bu are easy to separate.

Cyclotella kuetzingiana THWAITES is similar to Cyclotella paleo-ocellata in the presence of depressions in the central area (see HÃKANSSON 2002, figs 330-337; Houk et al. 2010, fig. 189: 1-6). However, C. kuetzingiana has a larger valve diameter $(8-45 \mu \mathrm{m}$ vs. $15-28 \mu \mathrm{m}$ in C. paleo-ocellata) and marginal fultoportulae positioned on every 2-4(5) costae, while in C. paleo-ocellata the marginal fultoportulae are
separated by $(0) 1-2$ costae. Additionally, the central area depressions in $\mathrm{C}$. kuetzingiana lack any patte of arrangement. Valves some papillae (see Houk et al. 2010, fig. 188: 1-6, fig. 189: $1-5$ ) and their number and arrangement is not equal as it is in C. paleo-ocellata. Also, no valves with more than seven central fultoportulae have been reported for C. kuetzingiana (HÁKANSSON 2002; Houk et al. 2010). Cyclotella kuetzingiana var. radiosa FrICKE has a similar radial arrangement of the central are depressions, but lacks any papillae, has smaller striae density $(12-14$ in $10 \mu \mathrm{m})$, only one rimoportula and arge number of radially arranged valve face central fultoportulae (see Houk et al. 2010, fig. 192: 1-6).

Cyclotella tripartita HAKANSSON (1990a, p. 76, figs $1-4,8-11,13)$ has a smaller valve diameter $(2-18$ $\mu \mathrm{m})$, fewer central fultoportulae ( $\max 2-3$ vs. $2-8$ in C. paleo-ocellata) and there are 4-7 costae (instead of (0)1-2 in C. paleo-ocellata) between the margina fultoportulae. Most definitively, C. tripartita lacks the typical orbiculi depressi. The central area is instea divided into six sections, three of them depressed having a triangular punctate field (HÁKANSSON 1990a). The rimoportula is located at a rather large distance from the costae, contrary to $C$. paleo-ocellata where the rimoportulae are located immediately next to the costae.

Cyclotella rossii Håkansson (1990b, p. 267 figs 18-27, 46-49) has an equal number of costae between the marginal fultoportulae but is smaller (valve diameter 5-18 $\mu \mathrm{m}$ vs. $15-28 \mu \mathrm{m}$ ) with 2-3, sometimes 5 , central fultoportulae. The species again lacks the typical orbiculi depressi but is characterized instea by 2-8 radial rows of puncta (HÁKANSSON 1990b). The rimoportula in the valve interior is well separated from the costae, contrary to the new taxo

Cyclotella pantanelliana CASTRACANE (1886, p. 171) is larger (valve diameter up to $70 \mu \mathrm{m}$ ) with a lower number of marginal striae (only 12-14 in 10 $\mu \mathrm{m})$ and lacks the typical orbiculi depressi, being characterized by radial series of large, coarse puncta, clearly penetrating the cell wall, which can be observed in LM during focus changing (Houk et al. 2010). Therefore, eroded valves of C. paleo-ocellat might look somewhat similar to $C$. pantanelliana. The arrangement of the marginal fultoportulae is also similar (separation by only 1 costa; Houk et al. 2010) and can produce some confusion. The marginal area of C. pantanelliana shows typical forked thinner costa between thickened ribs, which could also be confused with the forked interstriae of $C$. paleo-ocellata. However, no SEM observations have been made on the taxon of $C$. pantanelliana due to the fact that type aterial from Italy is no longer available.

Cyclotella polymorpha MeYer \& HÁKANsSON (1996, p. 64, figs 1-29) has a smaller valve diameter (4.5 $\mu \mathrm{m}-16 \mu \mathrm{m})$ with a contrasting central area morphology which lacks the typical concentrically arranged orbiculi depressi. Both taxa are easy to distinguish by their characteristic central area: Cyclotella polymorph shows a high variability of ornamentation patterns (i.e. radial rows of depressions with granulae on the raised area or 1-5 larger depressions having occasionally papillae in between (Houk et al. 2010) irregularly arranged in the central area in conparison to C. paleoocellata. Striae are usually of unequal length and usually penetrate deep into the central area. The central area is by this fact sometimes not clear to delimit in $C$. polymorpha, whereas it is easily in C. paleo-ocellata. Cyclotella polymorpha becomes more abundan in the upper parts of the sediment sequence from Lake Kinneret and also occurs in the modern diatom flora. Its increase occurs at the expanse of C. paleo-ocellata, which is replaced completely at ca. 2500 cal yrs BP (Vossel unpublished).

Finally, Cyclotella paraocellata CVETKOsKA, HAMILTON, OGNJANOVA-RUMENOVA \& LEVKOV (2014, p. 317 , figs $1-23,30-45$ ) is rather similar to C. paleoocellata but can nevertheless be separated based on the lower number of orbiculi depressi (3-6), unequal stria length, a constant, higher number of rimoportulae (3 vs. $1-3$ in C. paleo-ocellata) and a lower number of central fultoportulae (3-5). The central area of C. paraocellata is smaller than that of C. paleoocellata ( $40-50 \%$ vs. $50-75 \%$ of the valve diameter) The largest difference is the arrangement of the marginal fultoportulae, separated by $3-5$ costae in $C$. paraocellata compared to (0) $1-2$ costae in $C$. paleoocellata. Although CVETKOSKA et al. (2014) reported valves with twinned orbiculi depressi and papillae, the authors did not report any valves with multiple papillae arranged in a series

\section{Paleoecological remarks}

species of Cyclotella have evolved since the Miocene period in the Mediterranean region (CVETKOSKA et al. 2014). Cyclotella paleo-ocellata in Lake Kinneret is a new example. The date of first appearance of $C$. paleoocellata is at present unknown, pending recovery of the pre-Holocene sediment record. It is not yet possible to identify the exact environmental preferences of $C$. paleo-ocellata since the taxon is only known from subfossil assemblages. Ecological preferences can be inferred instead based on its association with other taxa of known ecology. Cyclotella paleo-ocellata is often abundant where $C$. ocellata is dominating the diatom flora, together accounting for almost $90 \%$ of the assemblage. Several Aneumastus taxa such as $A$. stroesei, are also present but at very low abundance. These taxa are known to prefer oligotrophic lakes (LANGe-Bertalot 2001)

As mentioned before, the broad ecological preference of $C$. ocellata makes ecological interpretations difficult. However, the period between
6500 and 3000 cal yrs BP is known as a humid phase Cycher than at prese (Have et a 2005). Cyclotella paleo-ocellata has large, thick robust silica frustules, suggesting based on life habit preferences of similar taxa [e.g., cylotelloid species from Lake Malawi, Afrika (HuISMAn \& SommeIJer 2002; Stone et al. 2011)] that it has an adaptive advantage in staying in suspension in deep turbulent open waters. Large varieties of the $C$. ocellata complex often seem to occu in deeper open-water lakes [e.g., deeper phases of the aninna sequence in Greece (WILSON et al. 2008)]. Both Cyclotella paleo-ocellata an Stephanodiscus galileensis disappear at c. $2500 \mathrm{ca}$ yrs BP in the sediment record (Vosset, unpublished) Since this disappearance coincides with humaninduced eutrophication indicated by a phase of fores clearance and the cultivation of olive trees identified in the pollen record (SchieBel 2013), it can be inferre that C. paleo-ocellata developed in an oligotrophic phase of lake development and has low tolerance of nutrient enrichment. Convincingly, the decrease of Cyclotella paleo-ocellata coincides with the rise of a range of centric taxa which are strong indicators for eutrophication, including Cyclotella meneghiniana KüTzING, C. polymorpha, Aulacoseira granulata EHRENBERG and several small Stephanodiscus specie including S. hantzschii Grunow, S. minutulus KüTzING and $S$. medius HÁKANSSON also indicating a clea shift from oligotrophic to more eutrophic condition (Krammer \& Lange-Bertalot 1991).

ACKNowLEDGEMENTS
We would like to that

We would like to thank Prof. Dr. Thomas Litt, University of Bonn
for providing the core sample material from Lake Kinneret for providing the core sample material from Lake Kinneret, the
laboratory facilities and the financial support to $\mathrm{H}$. Vossel. Part of the research, including the drilling campaign, was supported
within the CRC 806 project "Our Way to Europe" funded by the German Science Foundation (DFG). This research was also partially project No. AVOZ60050516 funded by the Academy of Sciences of the Czech Republic. The Belspo CCAMBIO project provided funding to visit the scanning electron microscopy facilities at the
National History Museum in London. UK Dr Alex Ball the staff of National History Museum in London, UK. Dr. Alex Ball, the staff of
the IAA laboratory and Dr. Eileen J. Cox (Natural History Museum are thanked for their help with scanning electron microscopy. Hannah Vossel especially wants to thank the Studienstiffung des deutschen Volkes for the personal financial support during this study.

\section{REFERENCES}

BARUCH, U. (1986): The Late Holocene Vegetational History of Lake Kinneret (Sea of Galilee), Israel. - Paléorien

BATTARBEE, R.W. (1986): Diatom analysis. - In: Berglund, palaeohydrology. - pp. 527-670, Wiley, Chichester.
pala Castracane, F. (1886): Catalogo delle Diatomee rinvenute
da D. Pantanelli nel calcare biancastro friable 

Sovrapposto al bacino di lignite di Spoleto. - Processi
Verbali Societa Toscana di Scienze naturali di Pisa. Atti.: $1-171$.

Cremer, H. \& Wagner, B. (2003): The diatom flora in the ultra-oligotrophic El'gygytgyn, Chukotka. - Polar

CVetKoska, A.; Hamilton, P.B;

\& LeVKOV, Z (2014): OGNANOVA-RUMENOVA, N.

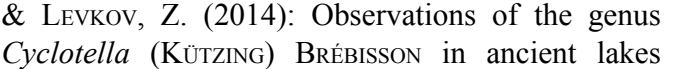
Ohrid and Prespa and a description of two new species $C$. paraocellata sp. nov. and C. prespanensis sp. nov. - Nova Hedwigia 98: 313-3.

Cvetкoska, A.; Refd, J.M. \& Levkov, Z. (2012): Diatoms as indicators of environmental change in ancien (ca. $140 \mathrm{ka})$. - In: WITKowsKI, A. (ed): Diatom Monographs 15. - 220 pp., ARG Gartner Verlag, Ruggell, Liechtenstein.

ЕнRцісн, А. (1985): The eco-biostratigraphic significance of the fossil diatoms of Lake Kinneret. - Geological Survey Israel Current Research 5:24-30

Енгцісн, А. (1995): Atlas of the Inland-water diatom flora of Israel. - In: PoR, F.D. (ed.): Flora Palaestina. - 166 pp., Geological Survey of Israel, Israel Academy of
Science and Humanities, Jerusalem.

Fritz, S.C.; Kingston, J.C. \& Engstrom, D.R. (1993): Quantitative trophic reconstruction from sedimentary
diatom assemblages: a Cutionary tale - Freshwater diatom assemblages: a Cautionary tale. - Freshwater Biology 30: 1-23.

ocellata-complex (Bacillariophyceae) from the Gallberg-pond, N.W.Germany. - Algological studies

86: 17-37.
HouK, V:; KleE, R. \& TANAKA H. (2010): Atlas of freshwater centric diatoms with a brief key and descriptions Discostella. - Fottea 10 (supplement): $1-498$. Huisman, J. \& SommeIJER, B. (2002): Maximal sustainable
sinking velocity of phytoplankton. - Marine Ecology Progress Series 244: 39-48

Hurwitz, S.; Garfunkel, Z.; Ben-Gal, Y.; Reznikov, M.; Rotsten, Y. \& GVIRTZMAN, H. (2002): The tectonic framework of a complex pull-apart basin: seismic Sea transform. - Tectonophysics 359: 289-306. K.T.; RоJo, K. \& COBELAS, A.M (1996): Morphological variability of a Cyclotella ocella (Bacillariophyceae) population in the Lake Las Madres (Spain). - Algological Studies 82: 37-55.

KIss, K.T.; KLEE, R. \& HEGEWALD, E. (1999): A reinvestigatio of the original material of Cyclotella ocellat PANTOCSEK (Bacillariophyceae). - - Algologica
Studies 93: 39-53.

Krammer, K. \& Lange-Bertalot, L. (1991): Bacillariophyceae 2/3. teil. Centrales, Fragilariaceae, Eunotiaceae. - In: ETtL, H.; GärTNer, G.; Gerlof
J.; Heyning, H. \& Mollenhauer, D. (eds): Süsswasserflora von Mitteleuropa. - 576 pp., Gustav Fisher Verlag, Stuttgart, New York.

Lange-Bertalot, H. (2001): Navicula sensu stricto, 10 genera separated from Navicula sensu lato, Frustulia. ,.S. \& PO 1-23. variability of Cyclotella ocellata from Lake Khubsgu (Mongolia). - Diatom Research 23: 75-91.

GopHEN, M. (2002): Water quality management in Lake Kinneret (Israel): hydrological and food web (2002). Residence time in lakes: Science, Management, Education. - Journal of Limnology 62: 91-101.

Hákansson, H. \& ЕнrцLCh, А. (1987): Stephanodiscus galileensis sp. nov. from Holocene subsurface sediments of Lake Kinneret. - Diatom Research HAKANSSON, H.

H. (1990a): Cyclotella tripartita nov. sp. (Bacillariophyceae) and the relationship to similar
taxa. - In: RICARD, M. (ed): Ouvrage dédié à mémoire du Professeur Henry Germain (1903-1989). -pp. 75-82, Koeltz Scientific Books, Königstein.

HákANSSON, H. (1990b): A comparison of Cyclotella krammeri sp. nov. and C. schumannii HÅKANSSON stat. nov. with similar species. - Diatom Research 5

HÁKANSSON, H. (2002): A compilation and evaluation of species in the genera Stephanodiscus, Cyclostephanos and Cyclotella with a new genus in the family
Stephanodiscaceae. - Diatom Research 17: 1-139.

Hazan, N.; Stein, M. \& Marco, S. (2004): Lake Kinnere levels and active faulting in the Tiberias area. - Israe Journal of Earth Science 53: 199-205.

Hazan, N.; Stein, M.; Agnon, A.; Marco, S.; Nadel, D. (2005): The J.F.W., SCHWAB, M.J. \& NEEV, D. Lake Kinneret (Sea of Galilee), Israel. - Quaternary Research 63: 60-77.

Hegewald, V.E. \& HindaKoví, A. (1997): Variability of
LitT, T.; Ohlwein, C.; Neunann, F.H.; Hense, A. \& Stein, M. (2012): Holocene climate variability in the Levant
from the Dead Sea pollen record. - Quaternary Science Reviews 49: 95-105.

MeYer, B. \& HÁKANSSON, H. (1996): Morphological variatio of Cyclotella polymorpha sp. nov. - Phycologia 35

64-69. Balaton. Im Auftrage des ungarischen geographische In: Resultate der wissenschaftlichen Erforschung des Balatonsees. II. Band. Anhang zur II. Section des 2. Victor Hornyánszky, Budapest.

Pollingher, U.; Ehrlich, A. \& Serruya, S. (1984): The Best 500 Years - Their contibution to the alga Biomass. - In: RICARD, M. (ed.): Proceedings of the International Diatom Symposium. - pp.
Koeltz Scientific Books, Koenigstein FRG.

Reed, J.M.; Stevenson, A.C. \& JugGins, S. (2001): A multi-proxy record of Holocene climatic change in southwestern Spain: the Laguna de Medina, Cádiz. The Holocene 11: 707-719.

Ross, R.; Cox, E.J.; Karayeva, N.I.; Mann, D.G.; Paddock, T.B.B.; Simonsen, R. \& Sims, P.A. (1979): An amended terminology for the siliceous components

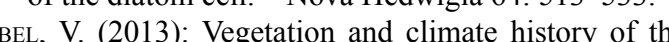
on palynological investigation $[\mathrm{PhD}$ thesis]. - 104 pp., Steinmann Institute of Geology, Mineralogy Theiles. $-112 \mathrm{pp}$. K. und K. Hofbuchdruckerei des planktonic diatoms of Lake Kinneret (Israel) during southern Levant during the last 30,000 yes of the
University of Bonn.
SChLEGEL, I. \& SChEFFLeR, W. (1999): Seasonal development and morphological variability of Cyclotella ocellata (German). Interntion Hydrobiologie 84: 469-478.

Stone, J.R.; Westover, K.S. \& CoHen, A.S. (2011): Late Pleistocene paleohydrography and diatom paleoecology of the central basin of Lake Malawi Africa. - Papers in the
Science. Paper 279: 52-70

Van Dam, H.; Mertens, A. \& Sinkeldam, J. (1994): A coded checklist and ecological indicator values of freshwater of Aquatic Eology 28: 117-133. WILSON, G.P.; ReED, J.M.; LaWson, I,

TzedAkis, P.C. \& PrefCE, R.C. (2008): Diatom response to the last glacial-interglacial transition in the Ioannina basin, northwest Greece: implication for Mediterranean palaeoclimate reconstruction. Quaternary Science Reviews 27: 428-440.

(C) Czech Phycological Society (2015)
Received June 6, 2014

Received Nower, 2014, 2014 